\title{
PERSEPSI SISWA KELAS XI SMA NEGERI 12 TERHADAP KEBERADAAN PROGRAM STUDY ILMU KOMUNIKASI PADA UNIVERSITAS KRISTEN INDONESIA MALUKU
}

\author{
Oleh Marleen Muskita, SP., M.Si
}

\begin{abstract}
Abstrak
Pengetahuan masyarakat terhadap keberadaan program study Ilmu Komunikasi pada Perguruan Tinggi Swasta khususnya UKIM dapat mempengaruhi berbagai persepsi dari masyarakat terhadap keberadaan dan output yang nanti akan dihasilkan dari Program Study Ilmu Komunikasi di Universitas Kristen Indonesia Maluku. Penelitian ini bertujuan untuk mengetahui persepsi siswa SMA kelas XI terhadap keberadaan Program Studi Ilmu Komunikasi pada Fakultas Ilmu Sosial dan Ilmu Politik di Universitas Kristen Indonesia Maluku.

Pemahaman mereka terhadap Program Studi Ilmu Komunikasi yang peneliti lakukan pada SMA Negeri 12, dapat dilihat bahwa hampir semua informan kurang paham tentang Program Studi Ilmu Komunikasi khususnya yang ada pada Universitas Kristen Indonesia Maluku.

Persepsi masyarakat terhadap keberadaan Program Studi Ilmu komunikasi dipengaruhi oleh faktor internal dalam diri serta faktor eksternal dari luar. Dimana kurangnya informasi yang diperoleh melalui penggunaan pola komunikasi yang berbeda di masyarakat, sehingga menimbulkan perbedaan persepsi yang juga menentukan pilihan masyarakat khususnya siswa-siswi SMA terhadap Perguruan Tinggi khususnya program studi setelah mereka lulus.
\end{abstract}

\section{PENDAHULUAN}

Dalam kehidupan manusia ada satu hal yang tak pernah terlepas yaitu belajar. Baik itu pembelajaran secara formal maupun non formal. Dalam pembelajaran formal kita mengetahuinya dengan istilah pendidikan. Pendidikan bertalian dengan transmisi pengetahuan, sikap, kepercayaan, ketrampilan, dan aspek-aspek kelakuan lainnya kepada generasi muda. Pendidikan adalah proses mengajar dan belajar pola-pola kelakuan manusia apa yang diharapkan oleh masyarakat. Pendidikan adalah salah satu kebutuhan utama 
manusia, karena melalui pendidikan seseorang akan mendapat pengetahuan yang begitu banyak. Pendidikan menjadi wadah untuk meregenerasikan kebiasaan maupun norma-norma atau nilai-nilai bagi penerus kita di masa yang akan datang.

Lembaga pendidikan (baik formal, non formal atau informal) adalah tempat transfer ilmu pengetahuan dan budaya. Lembaga pendidikan merupakan wadah untuk berlangsungnya pendidikan, maka tentunya akan mengangkut masalah lingkungan dimana pendidikan tersebut dilaksanakan. Cara masyarakat memandang pendidikan untuk anak-anaknya dapat diartikan sebagai persepsi. Leavitt (1978) menyatakan bahwa persepsi adalah pandangan atau pengertian, yaitu bagaimana seseorang memandang atau mengartikan sesuatu.

Proses persepsi terdiri dari dua tahap yaitu tahapan pertama terjadi pada penginderaan diorganisir berdasarkan prinsip-prinsip tertentu, tahapan kedua yaitu stimulus pada penginderaan diinterprestasikan dan dievaluasi. Persepsi masyarakat terhadap lembaga pendidikan khususnya pendidikan formal, dapat memberikan pengaruh bagi anak-anaknya kelak. Dengan banyaknya Perguruan Tinggi yang ada membuat masyarakat lebih selektif dalam pemilihan program study.

Melalui Proses komunikasi dimana pemakaian pikiran atau perasaan seseorang kepada orang lain. Pikiran tersebut dapat berupa idea, opini, mengenai hal yang konkret maupun yang abstrak. Bukan saja tentang suatu hal atau peristiwa yang terjadi pada saat sekarang, melainkan juga pada waktu yang lalu dan masa yang akan datang (Effendy, 2004:11).

Penggunaan pola komunikasi yang berbeda di masyarakat dapat memberikan pengaruh terhadap integrasi sosial sehingga menimbulkan perbedaan persepsi di masyarakat dalam menentukan pilihan terhadap masa depan anaknya ataupun pendidikan lanjutan di perguruan tinggi yang akan dipilih kelak setelah lulus SMA. Pendidikan tingkat tinggi dalam hal ini perguruan tinggi atau universitas harusnya memperhatikan hal tersebut. Program study Ilmu komunikasi kini menjadi salah satu program study unggulan di banyak universitasuniversitas besar di Indonesia yang mempunyai begitu banyak minat dari siswa. 
Setiap keputusan dan sifat selektif dari individu dipicu dengan persepsi mereka tentang masa depan, potensi mereka, prospek kedepan di dunia kerja, dan hal lainnya. Begitu pula dengan persepsi masyarakat tentang salah satu program studi yang ada di Maluku, yaitu Ilmu Komunikasi. Pengetahuan masyarakat terhadap keberadaan program study Ilmu Komunikasi pada Perguruan Tinggi Swasta khususnya UKIM dapat mempengaruhi berbagai persepsi dari masyarakat terhadap keberadaan dan output yang nanti akan dihasilkan dari Program Study Ilmu Komunikasi di Universitas Kristen Indonesia Maluku.

\section{Kerangka Teoritis}

\subsection{Persepsi}

\subsubsection{Pengertian Persepsi}

Persepsi diatikan sebagai suatu proses memperhatikan dan menyeleksi, mengorganisasikan dan menafsirkan stimulus lingkungan. Proses memperhatikan dan menyeleksi terjadi karena setiap saat panca indra (indra pendengar, perasa, penglihatan, penciuman, dan indra peraba) dihadapkan pada begitu banyak stimulus lingkungan. Ada juga beberapa pendapat para ahli mengenai pengertian persepsi. Dengan kata lain, persepsi mengubah sensasi menjadi informasi. Menurut Desiderato (1976:129) (dalam Rahkmat, 2003:51) persepsi ialah memberikan makna pada stimuli inderawi (sensory stimuly). Hubungan sensasi dengan persepsi sudah jalas sensasi adalah bagian dari persepsi

Persepsi berarti analisis mengenai cara mengintegrasikan penerapan kita terhadap halhal di sekeliling individu dengan kesan-kesan atau konsep yang sudah ada, dan selanjutnya mengenali benda tersebut. Untuk memahami hal ini, akan diberikan contoh sebagai berikut: individu baru pertama kali menjumpai buah yang sebelumnya tidak kita kenali, dan kemudian ada orang yang memberitahu kita bahwa buah itu namanya mangga.

Alport (dalam Mar'at, 1991) proses persepsi merupakan suatu proses kognitif yang dipengaruhi oleh pengalaman, cakrawala, dan pengetahuan individu. Pengalaman dan proses belajar akan memberikan bentuk dan struktur bagi objek yang ditangkap panca indera, sedangkan pengetahuan dan cakrawala akan memberikan arti terhadap objek yang ditangkap individu, dan akhirnya komponen individu akan berperan dalam menentukan tersedianya jawaban yang berupa sikap dan tingkah laku individu terhadap objek yang ada. 
Berdasarkan pendapat para ahli yang telah dikemukakan, bahwa proses persepsi melalui tiga tahap, yaitu:

a. Tahap penerimaan stimulus, baik stimulus fisik maupun stimulus sosial melalui alat indera manusia, yang dalam proses ini mencakup pula pengenalan dan pengumpulan informasi tentang stimulus yang ada.

b. Tahap pengolahan stimulus sosial melalui proses seleksi serta pengorganisasian informasi.

c. Tahap perubahan stimulus yang diterima individu dalam menanggapi lingkungan melalui proses kognisi yang dipengaruhi oleh pengalaman, cakrawala, serta pengetahuan individu.

\subsubsection{Faktor yang Mempengaruhi Persepsi}

Faktor yang mempengaruhi suatu persepsi individu ataupun kelompok terhadap suatu objek lain :

1. faktor yang ada pada perilaku persepsi (perceiver). Yang meliputi sikap, kebutuhan atau motif, kepentingan atau minat, pengalaman dan pengharapan individu.

2. Faktor yang pada objek atau target. Yang dipersepsikan meliputi hal-hal baru, gerakan bunyi, ukuran, latar belakang dan kedekatan

3. Faktor konteks situasi dimana persepsi dilakukan. Yang meliputi waktu, keadaan atau tempat dan keadaan sosial"'

Faktor lain yang menentukan sebuah persepsi adalah faktor fungsional yang berasal dari kebutuhan, pengalaman masa lalu dan hal lainnya yang dianggap personal. Menurut david Krech dan Richad S. Crutchfield (1997:235) seperti (dalam Rakhmat, 2003: 51), faktor fungsional dan faktor struktural sangat mempengaruhi persepsi, faktor tersebut antara lain :

a. Faktor fungsional. Faktor fungsional berasal dari kebutuhan, pengalaman masa lalu dan hal-hal lain yang termasuk apa yang kita sebut sebagai faktor-faktor personal yang menentukan persepsi bukan jenis atau bentuk stimuli, tetapi karakteristik orang yang memberikan respon pada stimuli itu.

b. Faktor struktural. Faktor struktural yang berasal semata-mata dari stimuli fisik dan efekefek syaraf yang ditimbulkannya pada system syaraf individu. Menurut Kohler (1957: 29) (dalam Rakhmat, 2003:58) yaitu : bagian-bagian medan yang terpisah (dari medan 
persepsi) berada dalam interdependensi yang dinamis (yakni dalam interaksi dan karena itu dinamika khusus dalam interaksi ini menentukan distribusi) fakta dan kualitas lokalnya maksudnya adalah jika kita ingin memahami suatu peristiwa, kita tidak dapat hubungan keseluruhan. Untuk memahami seseorang, kita harus melihatnya dalam konteksnya, dalam lingkungan, dalam masalah yang dihadapi”.

Persepsi atau suatu proses aktif timbulnya kesadaran dengan segera terhadap suatu obyek yang merupakan factor internal serta eksternal individu meliputi keberadaan onyek, kejadian dan orang lain melalui pemberian nilai terhadap obyek tersebut.

\subsection{Ilmu Komunikasi}

Istilah komunikasi dalam bahasa inggris adalah Communication berasal dari bahasa latin yaitu communication dan bersumber dari kata communis yang bearti sama, sama maksudnya adalah sama makna (Effendy, 2009:9). Jadi komunikasi adalah kesamaan makna yang dialami saat pesan disampaikan dari komunikator kepada komunikan. Dua para ahli yang memiliki pandangan berbeda terhadap pengertian komunikasi yaitu Everett M.Rogers, mengatakan bahwa komunikasi adalah proses dimana suatu ide dialihkan dari sumber kepada suatu penerima atau lebih, dengan maksud untuk mengubah tingkah laku mereka, sedangkan menurut Raymond S. Ross, komunikasi adalah suatu proses menyortir, memilih, dan mengirimkan simbol-simbol sedemikian rupa sehingga membantu pendengar membangkitkan makna atau respon dari pikirannya yang serupa dengan yang dimaksud komunikator (Mulyana, 2002:62).

Definisi diatas dapat disimpulkan bahwa komunikasi adalah proses pertukaran simbol atau lambang-lambang yang kemudian disebut pesan dari komunikator (pengirim) kepada komunikan (penerima) sehingga komunikator membantu pendengar membangkitkan makna atau respon dari pikirannya yang serupa dengan yang dimaksudkan komunikator.

Proses komunikasi adalah proses pemakaian pikiran atau perasaan seseorang kepada orang lain dengan menggunakan lambang (symbol) sebagai media. Pikiran tersebut dapat berupa idea, opini, mengenai hal yang konkret maupun yang abstrak. Bukan saja tentang suatu hal atau peristiwa yang terjadi pada saat sekarang, melainkan juga pada pada waktu yang lalu dan masa yang akan datang. Sedangkan lambang sebagai media primer dalam 
proses komunikiasi adalah bahasa, kiat, isyarat, gambar, warna dan lain sebagainya (Effendy, 2009:11).

Pemaparan dan penjelasan di atas maka dapat disimpulkan bahwa fungsi atau komunikasi sangat penting bagi kehidupan kita sehari-hari. Tanpa komunikasi kita tidak dapat berinteraksi dengan orang lain. Tidak ada satupun manusia yang dapat bertahan untuk tidak berkomunikasi karena dalam setiap kegiatan atau aktivitas manusia melakukan komunikasi atau interaksi dengan baik.Baik melakukan komunikasi verbal dan komunikasi nonverbal.

Bidang Ilmu komunikasi adalah ilmu yang mempelajari tentang tata cara berkomunikasi serta menggunakan berbagai alat komunikasi sebagai sarana komunikasi masyarakat. Kita tahu komunikasi bisa lewat komunikasi lisan maupun tulisan. Ilmu komunikasi merupakan ilmu yang mempelajari tentang komunikasi antar individu maupun kelompok.

Ilmu komunikasi merupakan ilmu yang strategi karena melibatkan manusia sebagai pelaku utamanya, juga berurusan dengan media yang merupakan sarana komunikasi. Sehingga ilmu komunikasi yang dipelajari dan dikaji adalah hal-hal yang akan terus ada sepanjang kehidupan manusia.

\section{METODOLOGI PENELITIAN}

\subsection{Jenis Penelitian}

Pendekatan yang digunakan dalam penelitian ini adalah pendekatan kualitatif dengan menggunakan metode penelitian studi kasus.Jenis penelitian studi kasus yakni menyelidiki sistematis atau suatu kejadian atau keadaan yang disebut sebagai kasus untuk memberikan penjelasan yang jujur dan seksama tentang suatu kasus tertentu dengan menggunakan caracara yang sistematis dalam melakukan pengamatan, pengumpulan data, analisis informasi, dan pelaporan hasilnya. Sehingga pembaca dapat memeriksa kebenaran tafsiran penulisannya dengan meninjau sejumlah data obyektif pilihan yang sesuai, yang dijadikan tumpuan untuk membangun studi kasus (Nisbet : 1994). Oleh karena itu pendekatan yang digunakan ialah pendekatan kualitatif.Kemudian pendekatan kualitatif dilakukan melalui kerja lapangan dan pengolahan data.

\subsection{Lokasi Penelitian}


Penelitian ini dilaksanakan di SMA Negeri 12 yang meliputi 20 siswa kelas XI.

\subsection{Jenis dan Sumber Data}

Jenis dan sumber data terdiri dari data primer dan data sekunder. Dapat dilihat penjelasannya di bawah ini yaitu :

a. Data Primer : data yang dihimpun secara langsung dari sumber berupa tanggapan langsung Informan yang didapat melalui Wawancara dan Observasi. Data primer disebut juga data asli atau data baru.Data ini juga diperoleh langsung dilapangan oleh penulis.

b. Data Sekunder : data pendukung penulis yang didapat dari bacaan-bacaan atau laporanlaporan peneliti terdahulu biasanya berupa arsip kepustakaan. Data sekunder ini disebut juga data tersedia. Data sekunder dalam penelitian ini berupa buku, majalah, internet dan sumber lain yang relevan dengan penelitian ini.

\subsection{Teknik Pengumpulan Data}

Dalam penelitian ini digunakan beberapa teknik pengumpulan data, bertujuan agar data-data yang dikumpulkan relevan dengan permasalahan penelitian. Adapun teknik-teknik pengumpulan data dalam penelitian ini adalah Teknik Observasi, Wawancara dan Dokumentasi.

\section{HASIL DAN PEMBAHASAN}

\subsection{Sajian dan Interpretasi Data}

\subsubsection{Persepsi siswa tentang Ilmu Komunikasi}

Informan dalam penelitian ini adalah dua puluh siswa-siswa kelas XI SMA Negeri 12 yang terdiri dari sepuluh siswi dan sepuluh siswa kelas XI. Dari semua informan yang ada, peneliti menemukan bahwa lebih banyak dari siswa-siswi ini yang mengetahui dan 
memahami tentang Ilmu Komunikasi, tetapi ada juga yang tidak mengetahui dan memahami tentang bidang Ilmu Komunikasi. Dari 20 siswa-siswi ada 17 siswa-siswi yang mengetahui dan memahami tentang Ilmu Komunikasi, dan sisanya tidak mengetahui dan memahami tentang bidang Ilmu Komunikasi.

\subsubsection{Persepsi siswa terhadap Program Studi Ilmu Komunikasi}

Terkait dengan persepsi siswa terhadap Program Studi Ilmu Komunikasi, dari kuesioner yang peneliti bagikan kepada 20 orang informan dalam hal ini siswa-siswi SMA Negeri 12, dapat dilihat apakah mereka memahami dan mengetahui tentang Program Studi Ilmu Komunikasi. Pemahaman mereka terhadap Program Studi Ilmu Komunikasi yang peneliti perhatikan dari hasil kuesioner yang peneliti bagi, dapat dilihat bahwa hampir semua informan kurang paham tentang Program Studi Ilmu Komunikasi, namun ada terdapat 5 informan yang paham tentang Program Studi Ilmu Komunikasi.

\subsection{Analisis Data}

Berdasarkan hasil temuan yang peneliti lakukan pada SMA Negeri 12 Ambon melalui wawancara tidak berstruktur terkait dengan persepsi siswa terhadap keberadaan Prodi Ilmu Komunikasi di UKIM, menunjukkan bahwa persepsi dari siswa-siswi berbeda dikarenakan informasi yang mereka peroleh tentang apa itu Ilmu Komunikasi maupun tentang Program Study Ilmu Komunikasi sanngat minim beredar di masyarakat.

Dapat dilihat dari hasil temuan yang peneliti dapati pada saat penelitian, dapat dilihat bahwa hampir sebagian besar informan tidak mengetahui dan tidak memahami tentang Program studi Ilmu Komunkasi. Kenyataan itu sangat berbeda dengan pemahaman mereka tentang Ilmu komunikasi. Hal tersebut dapat terjadi, karena dapat dipengaruhi oleh beberapa faktor yaitu Faktor Internal dan Faktor Eksternal, sehingga dapat mempengaruhi persepsi dari para informan. 
Persepsi merupakan proses yang terjadi di dalam diri individu yang dimulai dengan diterimanya rangsang, sampai rangsang itu disadari dan dimengerti oleh individu sehingga individu dapat mengenali dirinya sendiri dan keadaan di sekitarnya. Oleh karena itu faktor internal yang terdapat dalam diri individu seperti fisiologi, perhatian, minat, pengalaman, serta kebutuhan seseorang mencari obyek-obyek atau pesan yang dapat memberikan jawaban sesuai dengan dirinya sangat mempengaruhi persepsi masing-masing individu.

Kalau kita berbicara tentang ilmu komunikasi pasti kita harus tahu apa itu komunikasi. Kita tidak bisa untuk tidak berkomunikasi. Segala hal yang kita lakukan, dalam tujuan apapun, tentu memerlukan proses komunikasi. Proses menyampaikan pesan dari komunikator (penyampai pesan) kepada komunikan (penerima pesan) melalui suatu media atau cara hingga akhirnya menimbulkan suatu efek atau timbale balik, mungkin terlihat begitu sederhana. Seiring dengan berkembangnya zaman, waktu dan teknologi yang kian pesat, tentu segala unsur hidup kita menerima banyak pengaruh dari hal - hal baru. Hal - hal baru tersebut tentu mempengaruhi cara kita berkomunikasi.

Kurangnya informasi yang diperoleh informan tentang apa prospek dari Program Study Ilmu Komunikasi yang bisa mereka peroleh dari lingkungan sekitar ataupun dari apa yang mereka baca membuat sebagian besar informan tidak mengetahui dan memahami tentang profil dari program studi tersebut.

Padahal studi tentang Ilmu Komunikasi memiliki cabang yang cukup banyak. Broadcasting, jurnalistik, public relations, advertising, manajemen media, komunikasi pemasaran, komunikasi massa, komunikasi bisnis, dan masih banyak lagi. Biasanya, bila kita memilih salah satu dari cabang Ilmu Komunikasi tersebut, kita juga paham akan cabang cabangnya yang lain.

Pendidikan tingkat tinggi dalam hal ini perguruan tinggi atau universitas harusnya memperhatikan hal tersebut. Program study Ilmu komunikasi kini menjadi salah satu program study unggulan di banyak universitas-universitas besar di Indonesia yang mempunyai begitu banyak minat dari siswa.

Namun dari hasil penelitian yang dilakukan berkaitan dengan keberadaan Prodi ilmu Komunikasi di UKIM, kedapatan hampir sebagian besar informan tidak mengetahui dan tidak pernah mendengar adanya program studi Ilmu Komunikasi pada Universitas Kristen 
Indonesia Maluku. Hal itu dikarenakan kurangnya informasi yang mereka peroleh dari orang sekitar mereka seperti keluarga maupun kenalan mereka, dan juga sosialisasi-sosialisasi yang dilakukan oleh pihak kampus UKIM walaupun rutin dilakukan tiap tahunnya, tapi terlalu subjektif sehingga informasi yang diperoleh lebih ke penjelasan umum Universitas.

Penggunaan pola komunikasi yang berbeda di masyarakat dapat memberikan pengaruh terhadap integrasi sosial sehingga menimbulkan perbedaan persepsi di masyarakat dalam menentukan pilihan terhadap masa depan anaknya ataupun pendidikan lanjutan di perguruan tinggi yang akan dipilih kelak setelah lulus SMA.

Hal tersebut dapat mempengaruhi persepsi dari masyarakat terkhususnya siswa SMA yang akan melanjutkan studinya ke jenjang yang lebih tinggi yaitu Perguruan Tinggi. Pengetahuan mereka terhadap keberadaan program study Ilmu Komunikasi pada Perguruan Tinggi Swasta khususnya UKIM dapat mempengaruhi berbagai persepsi terhadap keberadaan dan output yang nanti akan dihasilkan dari Program Study Ilmu Komunikasi di Universitas Kristen Indonesia Maluku.

Oleh karena itu, sosialisasi-sosialisasi dan pengumuman penerimaan mahasiswa baru khususnya pada Program Studi Ilmu Komunikasi di UKIM harus lebih jelas spesifikasinya pada Prgram Studi Ilmu Komunikasi, agar menjadi fokus perhatian khusus bagi siswa-siswi yang akan melanjutkan studinya ke Perguruan Tinggi. Karena masa depan dari lulusan Ilmu Komunikasi ini dapat berkiprah baik dalam kancah nasional maupun internasional.

\section{PENUTUP}

\section{1. Kesimpulan}

Berdasarkan hasil penelitian yang dilakukan pada SMA Negeri 12 Ambon terkait dengan Persepsi Masyarakat terhadap keberadaan Program Studi Ilmu komunikasi, dapat ditarik kesimpulan bahwa persepsi masyarakat terhadap keberadaan Program Studi Ilmu komunikasi dipengaruhi oleh faktor internal dalam diri serta faktor eksternal dari luar. Dimana kurangnya informasi yang diperoleh melalui penggunaan pola komunikasi yang berbeda di masyarakat, sehingga menimbulkan perbedaan persepsi yang juga menentukan 
pilihan masyarakat khususnya siswa-siswi SMA terhadap Perguruan Tinggi khususnya program studi setelah mereka lulus.

\subsection{Saran}

Dari penelitian ini disarankan agar :

1. Penggunaan pola komunikasi antar masyarakat harus berpengaruh secara substansi dalam interaksi sosial masyarakat sehingga penyampaian informasi khususnya tentang keberadaan Program Studi Ilmu Komunikasi tersebar sampai masyarakat khususnya kepada siswa yang akan melanjutkan studi ke Perguruan Tingi.

2. Pihak Universitas Kristen Indonesia Maluku harus lebih memperhatikan penyebaran informasi tentang Program Studi Ilmu Komunikasi ke masyarakat, karena dilihat prospek dari lulusan Program Studi Ilmu Komunikasi sangat dibutuhkan di masyarakat.

\section{DAFTAR PUSTAKA}

Devito, Joseph A. 2007. Pearson International Edition. Printed in The United States of America : Pearson Education

Effendy, Onong Uchjana. 2009. Ilmu, Teori dan Praktek Komunikasi. Bandung : Remaja Rosdakarya

Mar'at, 1991. Sikap Manusia Perubahan Serta Pengukurannya. Jakarta: Ghalia Indonesia. Mulyana, Deddy. 2002. Metode Penelitian Kualitatif. Bandung : Remaja Rosdakarya Rakhmat, Jalaludin. 2003. Psikologi Komunikasi. Bandung : Remaja K Arya 